\title{
The helminth community of Geophagus proximus (Perciformes: Cichlidae) from a tributary of the Paraná River, Ilha Solteira Reservoir, São Paulo State, Brazil
}

\author{
A.C. Zago $^{1 *}$, L. Franceschini ${ }^{1}$, M.C. Zocoller- Seno ${ }^{2}$, R. Veríssimo- \\ Silveira $^{2}$, A.A.D. Maia ${ }^{3}$, C.V. Ikefuti ${ }^{4}$ and R.J. da Silva ${ }^{1}$ \\ ${ }^{1}$ UNESP - Universidade Estadual Paulista, Campus de Botucatu, Instituto \\ de Biociências, Departamento de Parasitologia, Botucatu, São Paulo, Brazil: \\ ${ }^{2}$ UNESP - Universidade Estadual Paulista, Campus de Ilha Solteira, \\ Departamento de Biologia e Zootecnia, Ilha Solteira, São Paulo, Brazil: \\ ${ }^{3}$ UNESP - Universidade Estadual Paulista, Campus de Ilha Solteira, \\ Departamento de Engenharia Civil, Ilha Solteira, São Paulo, Brazil: \\ ${ }^{4}$ UNESP - Universidade Estadual Paulista, Campus de Jaboticabal, \\ Centro de Aquicultura, Jaboticabal, São Paulo, Brazil
}

(Received 9 August 2011; Accepted 15 March 2012; First Published Online 25 April 2012)

\begin{abstract}
This study aimed to evaluate the helminth parasites of Geophagus proximus from the São José dos Dourados River, a tributary of Paraná River, Ilha Solteira Reservoir, São Paulo State, Brazil. From May 2006 to May 2007, 116 G. proximus specimens were examined and seven different taxa of helminth were collected and identified: proteocephalidean plerocercoids (Cestoda); metacercariae of Austrodiplostomum compactum, Clinostomum heluans and Clinostomum sp. (Trematoda); and Raphidascaris (Sprentascaris) hypostomi, and larvae of Raphidascaris sp. and Contracaecum sp. (Nematoda). All parasites presented the typical aggregated pattern of distribution, as well as the presence of a high number of larval stages, an absence of influence of the host sex and seasonality upon community parameters, as well as a correlation between species richness and host body weight. Moreover, with the exception of A. compactum metacercariae, all helminths found in this study are reported for the first time in G. proximus.
\end{abstract}

\section{Introduction}

The family Cichlidae Bonaparte, 1840 is one of the major vertebrate families, with at least 1300 species and approaching an estimated 1900 species (Kullander, 1998). Geophagus proximus (Castelnau, 1855) is included in this family and is commonly known in Brazil as the acará roi roi or acará tinga (Kullander, 2003). This fish species is

*E-mail: alinecristhina@yahoo.com.br native to Brazil and lives in the Amazon River basin, in the Ucayali River drainage of Peru, and along the stretch of the Solimões-Amazon River to the Trombetas River (Kullander, 2003). This species has recently been introduced to the Paraná River basin, through fishfarming (Langeani et al., 2007) and now has a prominent place in commercial fishing in the Ilha Solteira Reservoir which was previously occupied by endemic species of the Paraná River.

In the aquatic environment, the penetration of pathogens is facilitated and fish can be infected by 
numerous parasite species (Klein et al., 2004). Studies on the health of aquatic organisms have expanded in Brazil and several recent surveys have been conducted (Azevedo et al., 2006; Paes et al., 2010a, b; Zica et al., 2010, 2011). Several helminth species have been described parasitizing fish of the genus Geophagus Heckel, 1840, and G. brasiliensis Quoy \& Gaimard, 1824 presents the largest number of literature reports for the occurrence of parasites. With respect to the nematodes, there are records of Contracaecum sp. Railliet \& Henry, 1912 larvae in the visceral cavity (Kohn et al., 1988, 1989) and mesentery (Paraguassú et al., 2005; Carvalho et al., 2010); Procamallanus (Procamallanus) peraccuratus Pinto, Fabio, Noronha \& Rolas, 1976 (Pinto et al., 1976; Kohn et al., 1988; Carvalho et al., 2010), Raphidascaris sp. Railliet \& Henry, 1915 (Moravec et al., 1993) and Rhabdochona fasciata Kloss, 1964 (Paraguassú et al., 2005) in the intestine. In relation to cestodes, the occurrence of Proteocephalus gibsoni Rego \& Pavanelli, 1990 was reported by Rego \& Pavanelli (1990) in fish from the Amazon River, Brazil. For digenetic trematodes, Homalometron pallidum Stafford, 1904 has been reported in the stomach (Kohn \& Fernandes, 1981), Crassicutis cichlasomae Manter, 1936 was observed in the intestine, immature forms of Strigeidae Railliet, 1919 have been found encysted in the fins (Fernandes \& Kohn, 2001), Austrodiplostomum compactum (Lutz, 1928) metacercariae were observed in the eyes and swimbladder, Neascus Hughes, 1927 type 1 has been described in the eyes, Neascus type 2 in the tegument and Posthodiplostomum sp. Dubois, 1936 in the eyes, swimbladder and intestine (Carvalho et al., 2010).

Although G. proximus was first described in the 19th century, there are few records regarding its parasitic fauna. Takemoto et al. (2009) reported the occurrence of the nematode Raphidascaris (Sprentascaris) sp. Petter \& Cassone, 1984, the digenean Ascocotyle sp. Looss, 1899 metacercariae, two probable species of monogeneans of the genus Sciadicleithrum sp. Kritsky, Thatcher \& Boeger, 1989 and arachnids of the order Acarina in this fish species. Bellay et al. (2009) described two new species of monogeneans: Sciadicleithrum kritskyi Bellay, Takemoto, Yamada \& Pavanelli, 2009 and Sciadicleithrum paranaensis Bellay, Takemoto, Yamada \& Pavanelli, 2009; and Zica et al. (2010) observed A. compactum metacercariae in G. proximus from the Tietê River, Nova Avanhandava Reservoir, in the municipality of Buritama, São Paulo State, Brazil.

The aim of this study was to report the helminth fauna of G. proximus from the São José dos Dourados River, which is a tributary of the Paraná River, Ilha Solteira Reservoir, municipality of Ilha Solteira, São Paulo State, Brazil. This study employed a quantitative analysis of parasite community structure.

\section{Materials and methods}

\section{Parasitological procedures}

From May 2006 to May 2007, 10-11 specimens of G. proximus were collected monthly (except in January and February 2007), totalling 116 individuals. Fish were caught, using handmade fishing rods, from the São José dos Dourados River, a tributary of Paraná River,
Ilha Solteira Reservoir $\left(20^{\circ} 27^{\prime} 06.49^{\prime \prime}\right.$ S, 51 $16^{\prime}$ 07.31/"W), municipality of Ilha Solteira, São Paulo State, Brazil (fig. 1), and immediately taken to the laboratory, where necropsies were performed. The mean standard body length and body weight of fish were $12.87(9.2-17) \mathrm{cm}$ and $76.29(24-165.2) \mathrm{g}$, respectively. There was no significant difference ( $t$-test; $t=-0.95 ; P=0.34)$ in the standard body length of males $(n=46 ; 13.04 \pm 0.26 \mathrm{~cm})$ and females $(n=68 ; 12.75 \pm 0.19 \mathrm{~cm})$. The host sample was divided into four size class intervals, with amplitudes of $2 \mathrm{~cm}$ in length $(9-11 \mathrm{~cm}, 11.1-13 \mathrm{~cm}$, $13.1-15 \mathrm{~cm}$ and $15.1-17 \mathrm{~cm})$.

Organs and body cavities of G. proximus were examined and the helminths found were collected, fixed and stained, according to standard parasitology techniques (Eiras et al., 2006). Body surfaces were also examined for encysted metacercariae. For identification and diagnosis of parasites, the following references were used: Travassos et al. (1969), Kohn et al. (1995) and Gibson et al. (1996) for trematodes, Moravec et al. (1990) and Thatcher (2006) for nematodes, and Rego et al. (1999) for cestodes. For species identification, parasites were analysed using a computerized system for image analysis (Qwin Lite 3.1, Leica Microsystems, Wetzlar, Germany). Voucher specimens were deposited in the Coleção Helmintológica, of the Departamento de Parasitologia, Instituto de Biociências, Universidade Estadual Paulista - UNESP, municipality of Botucatu, São Paulo State, Brazil.

\section{Data analysis}

The ecological descriptors of the parasitism (prevalence, abundance and mean intensity of infection) were calculated according to Bush et al. (1997). Parasites were classified according to their prevalence in the core species (prevalence higher than $66.66 \%$ ), secondary species (prevalence from 33.33 to $66.66 \%$ ) and satellite species (prevalence lower than $33.33 \%$ ) with the aim of verifying the Importance Value, i.e. the importance of each species in the helminth parasite community (Bush \& Holmes, 1986).

The relationship between variance and mean of parasite abundance - dispersion index (Krebs, 1989) and the calculation of the $k$ parameter of the negative binomial distribution (Bliss \& Fisher, 1953) were used for each parasite species to determine their distribution patterns. Parasite species diversity was calculated using the Brillouin index $(H)$ with a logarithm to the base $e$. The condition factor (K), according to Le Cren (1951), is given by the relationship between body weight and body length of the individual and this was employed to verify the possible correlation with total parasite abundance, parasite species diversity and parasite species richness.

Comparison of the prevalence of each parasite species in relation to the host sex and seasonality was performed using the Z-test. The variation of intensity of infection, abundance, parasite species diversity and parasite species richness, according to sex and seasonality, were compared by Mann-Whitney's test $(U)$. Spearman's rank correlation $\left(r_{\mathrm{s}}\right)$ was used to study possible correlations of intensity of infection and abundance of each parasite species in relation to standard body length, weight and 


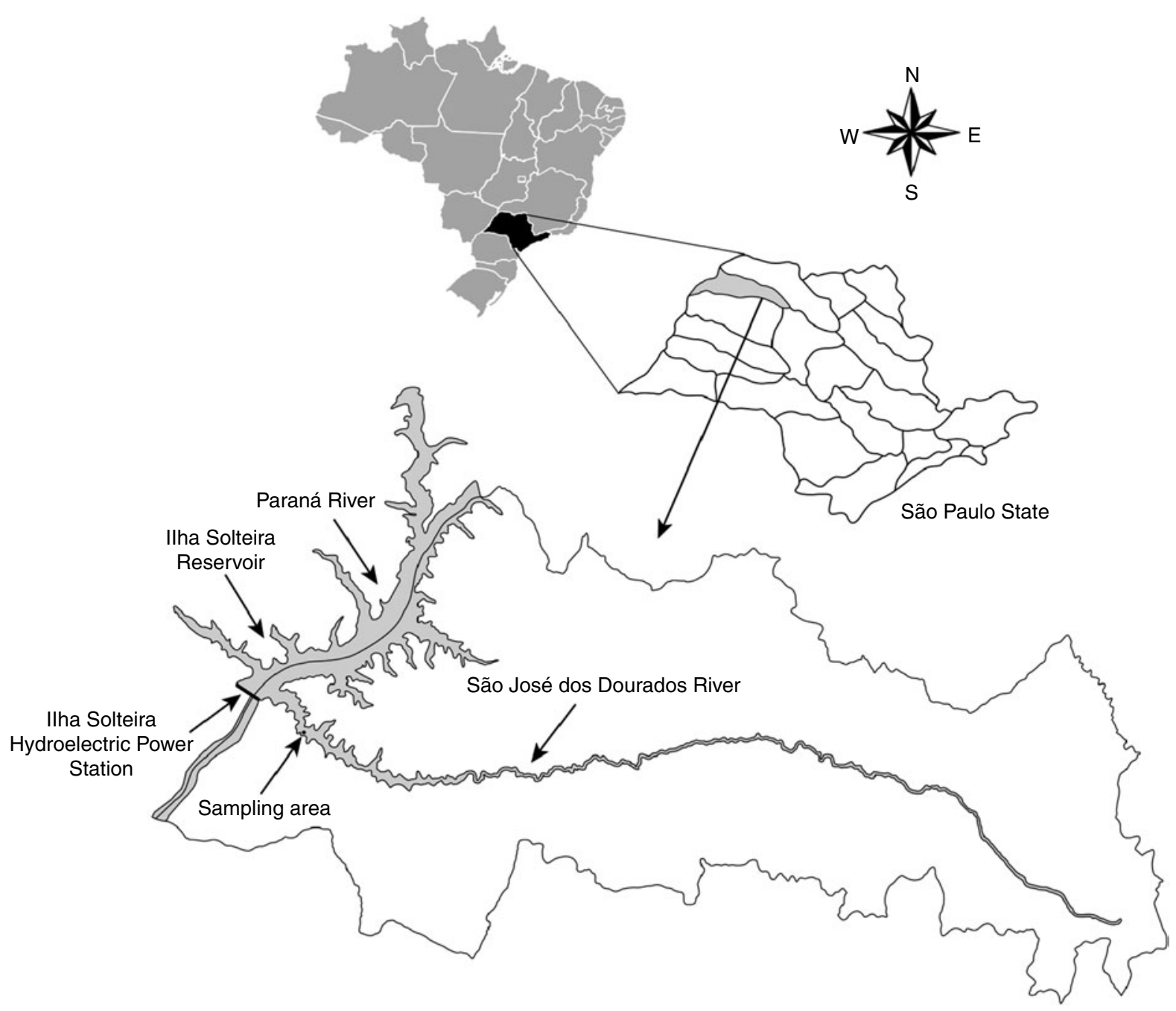

Fig. 1. Map of Brazil highlighting São Paulo State and the sampling area at São José dos Dourados River, a tributary of Paraná River, Ilha Solteira Reservoir, municipality of Ilha Solteira, São Paulo State, Brazil $\left(20^{\circ} 27^{\prime} 06.49^{\prime \prime} \mathrm{S}, 51^{\circ} 16^{\prime} 07.31^{\prime \prime} \mathrm{W}\right)$.

condition factor $(\mathrm{K})$ at the level of the community component during the whole year. This test was also used to verify the possible correlations of standard body length, body weight and condition factor $(\mathrm{K})$ of the hosts, in relation to total parasite abundance, parasite species diversity and parasite species richness at the level of infracommunity during the whole year.

Differences in abundance (Kruskal-Wallis), parasite species diversity and richness (one-way analysis of variance (ANOVA)) in relation to the host sex and seasonality among the size class intervals were checked. Statistical tests were performed using SigmaStat 3.1 (Systat Software Inc., California, USA), adopting a significance level of $5 \%$. Parasite species richness and parasite species diversity were calculated using the computer program MVSP 3.13 (Multivariate Statistical Package, Kovach Computing Services, Anglesey, Wales, UK) and parasite distributions were analysed using the Quantitative Parasitology 3.0 computer software (Rozsa et al., 2000).

\section{Results}

\section{Component community}

Cestodes were the most prevalent parasites (96.55\%), followed by digenetic trematodes $(60.34 \%)$ and nematodes $(26.72 \%)$. Seven different helminth parasite taxa were collected: Proteocephalidea gen. sp. plerocercoids (Cestoda), metacercariae of Austrodiplostomum compactum, Clinostomum heluans Braun, 1899 and Clinostomum sp. Leidy, 1856 morphotype 2 (Trematoda), and Raphidascaris (Sprentascaris) hypostomi (Petter \& Cassone, 1984), and larvae of Raphidascaris sp. and Contracaecum sp. (Nematoda) (table 1).

The large number of proteocephalidean plerocercoids did not allow the number of individuals to be counted and only the prevalence and Importance Value were calculated for this parasite taxa. Proteocephalidean plerocercoids were found in $96.55 \%$ of the G. proximus examined and were the most prevalent parasites (table 1). According to their prevalence, only proteocephalidean 
plerocercoids were considered as a core species, A. compactum metacercariae constituted a secondary species and R. (S.) hypostomi, Raphidascaris sp. larvae, Contracaecum sp. larvae, C. heluans metacercariae and Clinostomum morphotype 2 metacercariae were satellite species (table 1).

The dispersion index and the $k$ parameter of the negative binomial distribution (for which the observed and expected frequencies did not differ significantly) indicated that the majority of parasite species of G. proximus presented the typical aggregated pattern of distribution (table 2). The prevalence (Z-test), intensity of infection and abundance (Mann-Whitney's test) of each parasite species of G. proximus were not significantly different between male and female hosts and did not differ in relation to seasonality $(P>0.05)$. The intensity of infection and the abundance of each parasite species did not correlate with host body length, weight or condition factor $(P>0.05)$.

\section{Infracommunities}

Ninety-seven per cent of G. proximus were parasitized by at least one helminth species. Three hundred and thirty-eight individual parasites were collected, with a mean of 2.91 parasites/fish. Associations between the total parasite abundance and the standard body length $\left(r_{\mathrm{s}}=0.11, P=0.24\right)$, body weight $\left(r_{\mathrm{s}}=0.18, P=0.05\right)$ and condition factor $\left(r_{\mathrm{s}}=0.13, P=0.18\right)$ of $G$. proximus were not observed. Therefore, the total parasite abundance was not different between size class intervals $(H=4.69$, $P=0.20)$.

The mean parasite species richness was $1.99 \pm 0.08$ $(0-4)$ and was not related to seasonality $(U=1959.5$, $P=0.36)$, host sex $(U=2638, P=0.97)$ or size class intervals $(H=4.56, P=0.21)$. Parasite species richness was positively correlated to the body weight of fish $\left(r_{\mathrm{s}}=0.20, P=0.03\right)$, but not to standard body length $\left(r_{\mathrm{s}}=0.14, P=0.15\right)$ and condition factor $\left(r_{\mathrm{s}}=0.16\right.$, $P=0.10)$.

The mean parasite species diversity $(H)$ was $0.14 \pm 0.03$ and the maximum diversity value was 0.80 . Parasite species diversity showed no significant differences in relation to seasonality $(U=1117.50, P=1)$, host sex $(U=1449.5, P=0.07)$ and size class intervals $(H=3.63$, $P=0.12$ ), and there was also no correlation with body weight $\left(r_{\mathrm{s}}=0.11, P=0.29\right)$, standard body length $\left(r_{\mathrm{s}}=0.12, P=0.22\right)$ or condition factor $\left(r_{\mathrm{s}}=0.09\right.$, $P=0.33)$.

\section{Discussion}

The present study evaluated the helminth parasite community of G. proximus from São José dos Dourados River, a tributary of Paraná River, Ilha Solteira Reservoir, São Paulo State, Brazil. Seven different taxa of parasites were found and some patterns of the parasite community structure were observed, as follows: a high prevalence of proteocephalidean plerocercoids, a high number of larval stages, absence of influence of the host sex and seasonality upon community parameters, correlation 
Table 2. Dispersion index (DI) and $k$ parameter of the negative binomial distribution of the helminth parasites of Geophagus proximus from the São José dos Dourados River, a tributary of Paraná River, Ilha Solteira Reservoir, municipality of Ilha Solteira, São Paulo State, Brazil.

\begin{tabular}{lcc}
\hline Parasites & DI & $k^{\mathrm{a}}$ \\
\hline Austrodiplostomum compactum (Lutz, 1928) (metacercariae) & 6.75 & 0.53 \\
Raphidascaris (Sprentascaris) hypostomi (Petter \& Cassone, 1984) & 3.3 & 0.12 \\
Raphidascaris sp. Railliet \& Henry, 1915 (larvae) & 10.09 & 0.09 \\
Clinostomum heluans Braun, 1899 (metacercariae) & 3.88 & 0.04 \\
Clinostomum sp. morphotype 2 Leidy, 1856 (metacercariae) & - c $^{\mathrm{c}}$ & $-^{\mathrm{b}}$ \\
Contracaecum sp. Railliet \& Henry, 1912 (larvae) & 1.83 & $-^{\mathrm{b}}$ \\
\hline
\end{tabular}

${ }^{\text {a }}$ Observed and expected frequencies do not differ significantly (at $P=0.05$ ).

${ }^{\mathrm{b}}$ Not enough categories: fit to the negative binomial cannot be tested.

${ }^{\mathrm{c}}$ Dispersion index was not calculated because only one host was infected by this parasite.

between species richness and host body weight, and the aggregated pattern of distribution for all parasites.

The high prevalence of plerocercoids found in these fish may be related to their diet, which includes copepods that can act as first intermediate hosts of proteocephalideans. Moretto et al. (2008) examined the stomach contents of G. proximus from the Tietê River Basin, São Paulo State, Brazil, and found that copepods, along with other food items, such as molluscs, sediment, decomposing organic matter, allochthonous plant fragments and insects, were food items of the diet of this fish species. Plerocercoids found in G. proximus formed tissue-like masses that resemble adipose or testicular formations in the visceral cavity, as reported by Thatcher (2006). In some cases, a chronic inflammatory response that involves the encapsulation of the parasites by collagenous connective tissue may occur (O'Neill et al., 1988).

Metacercariae of digenetic trematodes presented the second highest prevalence among the parasites studied. The abundance and intensity of the infection of $A$. compactum in G. proximus did not correlate with body length, body weight or condition factor. This parasite species was found in the eyes of G. proximus and, according to Eiras (1994), the presence of parasites in this organ can cause blindness or impair vision, causing the fish to become an easier prey for capture by the definitive host (in this case, piscivorous birds), so that the parasite can complete its life cycle faster.

In Brazil, A. compactum metacercariae have been reported in several fish species (Santos et al., 2002; Machado et al., 2005; Yamada et al., 2008; Takemoto et al., 2009; Zica et al., 2009, 2011; Paes et al., 2010a, b), and were recently found in G. proximus from the Nova Avanhandava Reservoir, Medium Tietê River, Brazil (Zica et al., 2010). In the present study, the prevalence of A. compactum in G. proximus was lower than that found by Zica et al. (2010). The high prevalence of $A$. compactum metacercariae, according to Zica et al. (2010), could be related to the fact that this fish species has been introduced; its high susceptibility to infection by this trematode was similar to that found in Plagioscion squamosissimus Heckel, 1840, which is also an introduced species and highly susceptible to this parasite. The fact that the prevalence of $A$. compactum metacercariae in the present study was lower than that found by Zica et al. (2010) may be related to the low presence of molluscs (intermediate hosts of this parasite) in the Ilha Solteira
Reservoir, due to environmental characteristics such as the low quantity of organic matter and aquatic vegetation (Milward-de-Andrade, 1959; Madi, 2005) or due to the population size of the definitive host, which may be lower in the reservoir studied (Madi, 2005). The fact that the intensity of infection of $A$. compactum was not correlated with host body length and weight may be related to the method of parasite infection (active penetration) and thus this parasite species could infect young and adult fish in the same manner.

Metacercariae of the genus Clinostomum were also found in G. proximus, but with low prevalence, mean intensity of infection and mean abundance. Paraguassú et al. (2005), studied G. brasiliensis from the Lajes Reservoir, Rio de Janeiro State, Brazil, and found results similar to those observed in this study for this parasite. Clinostomum spp. metacercariae are responsible for the yellow spot disease in freshwater fish (Silva et al., 2008). In Brazil, Clinostomum spp. metacercariae have been reported in several fish species, including G. brasiliensis (Paraguassú et al., 2005), Astyanax altiparanae Garutti \& Britski, 2000, Acestrorhynchus lacustris Lütken, 1875, Schizodon borellii Boulenger, 1900, Pimelodus maculatus Lacepède, 1803, and Cichla kelberi Kullander \& Ferreira, 2006 (Takemoto et al., 2009).

In our sample, two Clinostomum species were found. However, only one of these could be identified, and this species was closely related to C. heluans (fig. 2) and was present in seven host specimens. Another Clinostomum sp. metacercaria was damaged during collection and the identification to the species level was not possible. However, this species was very different to that of the first species observed and was considered as morphotype 2 . This metacercaria was found in only one G. proximus specimen and its morphology is closely related to that of Clinostomum complanatum Rudolphi, 1814. Future studies will be necessary to confirm this. In relation to $C$. heluans, there are no reports of fish parasitized by metacercariae of this species; however there are reports of molluscs (Moraes et al., 2009) and piscivorous birds (Travassos et al., 1969) infected by this trematode. Fish containing metacercariae have a zoonotic potential if eaten raw or undercooked (Kitagawa et al., 2003) and some human cases have been published. Tiewchaloern et al. (1999) reported the presence of Clinostomum sp. in the eye of a Thai man, and Chung et al. (1995) found C. complanatum parasitizing the pharynx of a man in Korea. In Brazil, 


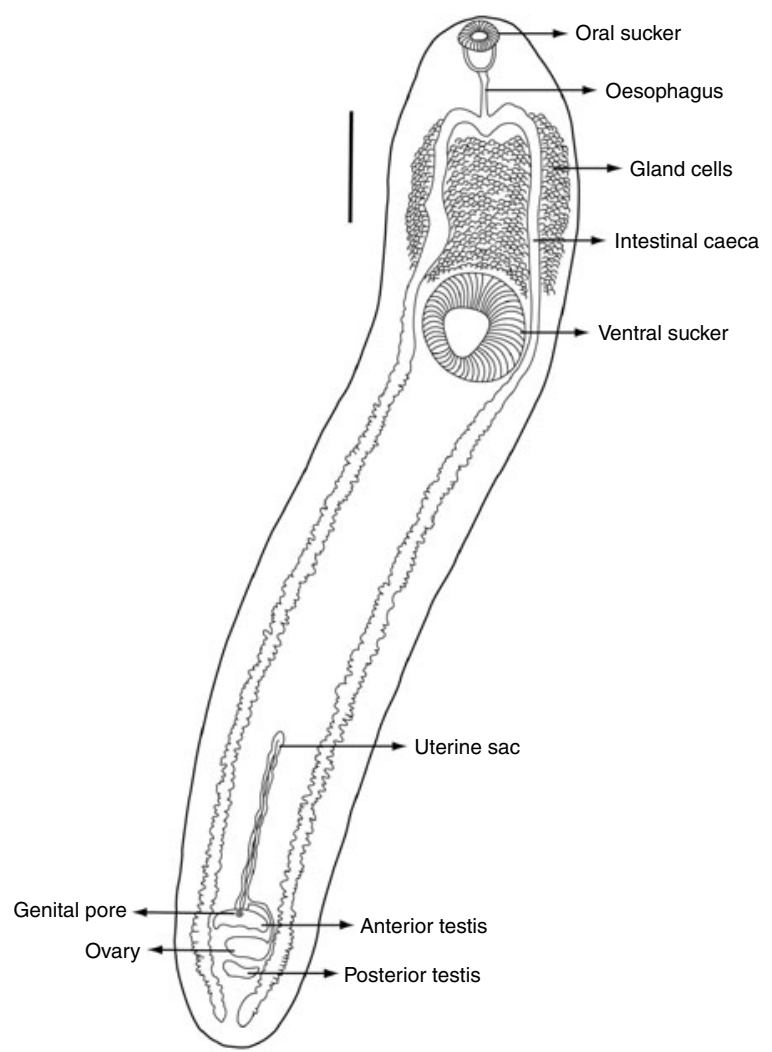

Fig. 2. Clinostomum heluans metacercaria collected in the fins of Geophagus proximus from São José dos Dourados River, a tributary of Paraná River, Ilha Solteira Reservoir, municipality of Ilha Solteira, São Paulo State, Brazil. Scale bar $=500 \mu \mathrm{m}$.

there are no reports of infection with these trematode metacercariae in humans.

The nematodes found in the present study are included in the family Anisakidae Skrjabin \& Karokhin, 1945, and represented the group of parasites with the lowest prevalence. Anisakids are associated with aquatic organisms (fish and marine mammals) and piscivorous birds, and the transmission of species in this family is dependent upon water and frequently involves aquatic invertebrates and fish intermediate or paratenic hosts (Anderson, 2000). In this study, we found one anisakid species in the adult stage ( $R$. (Sprentascaris) hypostomi) and two anisakid species in the larval stage (Raphidascaris sp. and Contracaecum sp.), suggesting that G. proximus can act as a definitive and intermediate host to nematodes of this family.

Nematode larvae of the family Anisakidae are important in public health, because they may be responsible for the emerging disease, anisakiasis. Humans acquire this infection by eating raw food dishes such as sushi, sashimi, ceviche or undercooked fish and squid dishes (Sakanari \& McKerrow, 1990). This disease occurs mainly in countries whose populations have the habit of eating raw fish, such as those belonging to the Asian continent (Asami et al., 1965; Sohn \& Seol, 1994). In Brazil, there are no reports of cases in humans, although studies show the occurrence of fish infected with these larvae
(Bicudo et al., 2005; Barros et al., 2007; Knoff et al., 2007). Considering the site of infection of anisakid larvae in G. proximus it was not possible to confirm their zoonotic potential because none of these species were found in the host musculature.

With regard to $R$. (Sprentascaris) hypostomi, there have been few studies reporting the occurrence of this parasite species in fishes. Moravec et al. (1990) reported its occurrence in the intestine and stomach of Hypostomus albopunctatus Regan, 1908 (=Plecostomus albopunctatus Regan, 1908), H. commersoni Valenciennes, 1836 (=P. commersoni Valenciennes, 1836), H. derbyi Haseman, 1911 $(=P$. derbyi Haseman, 1911) and Ancistrus cirrhosus Valenciennes, 1836, in Salto Osório, Paraná State, Brazil and Passo Fundo, Rio Grande do Sul State, Brazil. This nematode was also found infecting $H$. cochliodon Kner, 1854 (=Cochliodon cochliodon Kner, 1854), Hypostomus sp. Lacépède, 1803, and Ancistrus cirrhosus (Thatcher, 2006).

The majority of helminths found in G. proximus were in the larval stage, suggesting that this fish species occupies an intermediate position in the food chain and may be part of the diet of many species of piscivorous birds (definitive hosts of Contracaecum sp., A. compactum and Clinostomum sp.), as well as fish, amphibians and reptiles, which are definitive hosts of proteocephalidean plerocercoids (Silva et al., 2000; Alves \& Luque, 2006). Paraguassú et al. (2005) studied the structure of the parasite infracommunity of G. brasiliensis in the Lajes Reservoir, Rio de Janeiro State, Brazil, and some characteristics observed were similar to those found for G. proximus in the Ilha Solteira Reservoir, São Paulo State, Brazil. The parasites showed the typical aggregated pattern of distribution, all parasite species did not present a correlation between body length and parasite prevalence and abundance, the sex of hosts did not influence the prevalence or the abundance of any parasite species, and mean parasite species diversity was not correlated with body length.

The aggregated pattern of distribution, presented by all parasites found in G. proximus in this study, is a common feature of infections in invertebrate and vertebrate hosts (Zuben, 1997). Thus, most hosts harboured fewer parasites while only a small number of hosts harboured a large proportion of the parasite population (Zuben, 1997). Many biological forces operate to shape the distribution of parasites among hosts and the causes of the aggregated pattern of distribution are many and varied, because they are usually associated with variability in susceptibility to infection within the host population (Anderson, 1993; Poulin, 2007). Such variability may be due to differences in the spatial aggregation of infective stages, host behaviour, or differences in the ability of hosts to mount effective immunological responses to parasite invasion (due to past experiences of infection, other parasitic species within the host or genetic constitution) (Anderson, 1993). The hosts with heavy infections are often predisposed to this state by, as yet undetermined, factors involving genetic, behavioural and environmental components (Anderson, 1993). Although the parasites found in G. proximus presented low values of mean species richness and mean species diversity, they were similar when compared with studies carried out with another fish species belonging to the 
family Cichlidae from Brazil (Paraguassú et al., 2005; Azevedo et al., 2006, 2007).

In the present study, neither the body length nor condition factor $(\mathrm{K})$ was correlated with the rates of parasitism. The number of species (richness) of parasite infracommunities varies among host individuals in a population, among host populations and among host species (Poulin, 1995). According to Bell \& Burt (1991), who analysed the mean number of parasitic helminth species among Canadian freshwater fish, the helminth diversity is positively correlated with host size, longevity, diet and geographical range. Therefore, the lack of relationship between the rates of parasitism and the host body length or condition factor $(\mathrm{K})$ could indicate that the diet of G. proximus does not vary according to their growth, indicating homogeneity in its behaviour during the life cycle and permitting the uniform recruitment of the same species of parasites throughout ontogenetic evolution (Machado et al., 1996).

There was no influence of the sex of the host and seasonality upon the rates of parasitism in G. proximus. These parameters are important factors in the hostparasite relationship and the pattern found suggests that ecological relationships, such as behaviour, habitat and diet, and physiological resistance between male and female hosts are similar (Abdallah et al., 2005; Azevedo et al., 2007). With regard to seasonality, there are no well-defined seasons in Brazil and this characteristic may have contributed to the lack of relationship between parasitism rates and seasonality.

In summary, seven taxa of helminths were found in G. proximus from the São José dos Dourados River, a tributary of Paraná River, Ilha Solteira Reservoir, municipality of Ilha Solteira, São Paulo State, Brazil. A high rate of infection with larval stages was observed, as well as the absence of the influence of the host sex and seasonality upon community parameters. Correlation between species richness and host body weight was also not observed. Moreover, with the exception of A. compactum metacercariae, all helminths found in this study are reported for the first time in G. proximus.

\section{Acknowledgements}

The authors thank the Fundação de Amparo a Pesquisa do Estado de São Paulo (FAPESP) for financial support (Process 2008/58619-8). The authors thank Dr Nicola Conran for assistance with the English language review.

\section{References}

Abdallah, V.D., Azevedo, R.K. \& Luque, J.L. (2005) Ecologia da comunidade de metazoários parasitos do sairú Cyphocharax gilbert (Quoy \& Gaimard, 1824) (Characiformes: Curimatidae) do rio Guandu, Estado do Rio de Janeiro, Brasil. Revista Brasileira de Parasitologia Veterinária 14, 154-159.

Alves, D.R. \& Luque, J.L. (2006) Ecologia das comunidades de metazoários parasitos de cinco espécies de escombrídeos (Perciformes: Scombridae) do litoral do Estado do Rio de Janeiro, Brasil. Revista Brasileira de Parasitologia Veterinária 15, 167-181.
Anderson, R.C. (2000) Nematode parasites of vertebrates: their development and transmission. 2nd edn. $650 \mathrm{pp}$. New York, CABI Publishing.

Anderson, R.M. (1993) Epidemiology. pp. 75-116 in Cox, F.E.G. (Ed.) Modern parasitology: a textbook of parasitology. 2nd edn. Oxford, Blackwell Publishing.

Asami, K., Watanuki, T., Sakai, H., Imano, H. \& Okamoto, R. (1965) Two cases of stomach granuloma caused by Anisakis-like larval nematodes in Japan. American Journal of Tropical Medicine and Hygiene 14, 119-123.

Azevedo, R.K., Abdallah, V.D. \& Luque, J.L. (2006) Ecologia comunidade de metazoários parasitos do acará Geophagus brasiliensis (Quoy e Gaimard, 1824) (Perciformes: Cichlidae) do rio Guandu, Estado do Rio de Janeiro, Brasil. Acta Scientiarum Biological Sciences 28, 403-411.

Azevedo, R.K., Abdallah, V.D. \& Luque, J.L. (2007) Ecologia da comunidade de metazoários parasitos do apaiarí Astronotus ocellatus (Cope, 1872) (Perciformes: Cichlidae) do rio Guandu, Estado do Rio de Janeiro, Brasil. Revista Brasileira de Parasitologia Veterinária 16, 15-20.

Barros, L.A., Moraes-Filho, J. \& Oliveira, R.L. (2007) Larvas de nematóides de importância zoonótica encontradas em traíras (Hoplias malabaricus Bloch, 1794) no município de Santo Antonio do Leverger, MT. Arquivo Brasileiro de Medicina Veterinária e Zootecnia 59, 533-535.

Bell, G. \& Burt, A. (1991) The comparative biology of parasite species diversity: internal helminths of freshwater fish. Journal of Animal Ecology 60, 1047-1064.

Bellay, S., Takemoto, R.M., Yamada, F.H. \& Pavanelli, G.C. (2009) Two new species of Sciadicleithrum (Monogenea: Dactylogyridae), gill parasites of Geophagus proximus (Castelnau) (Teleostei: Cichlidae), from the upper Paraná River floodplain, Brazil. Zootaxa 2081, 57-66.

Bicudo, A.J.A., Tavares, L.E.R. \& Luque, J.L. (2005) Larvas de Anisakidae (Nematoda: Ascaridoidea) parasitas da cabrinha Prionotus punctatus (Bloch, 1793) (Osteichthyes: Triglidae) do litoral do Estado do Rio de Janeiro, Brasil. Revista Brasileira de Parasitologia Veterinária 14, 109-118.

Bliss, C.I. \& Fisher, R.A. (1953) Fitting the negative binomial distribution to biological data. Biometrics 9, 176-200.

Bush, A.O. \& Holmes, J.C. (1986) Intestinal helminths of lesser scaup ducks: an interactive community. Canadian Journal of Zoology 64, 142-152.

Bush, A.O., Lafferty, K.D., Lotz, J.M. \& Shostak, A.W. (1997) Parasitology meets ecology on its own terms: Margolis et al. revisited. Journal of Parasitology 83, 575-583.

Carvalho, A.R., Tavares, L.E.R. \& Luque, J.L. (2010) Variação sazonal dos metazoários parasitos de Geophagus brasiliensis (Perciformes: Cichlidae) no rio Guandu, Estado do Rio de Janeiro, Brasil. Acta Scientiarum Biological Sciences 32, 159-167.

Chung, D., Moon, C., Kong, H., Choi, D. \& Lim, D. (1995) The first human case of Clinostomum complanatum (Trematoda: Clinostomidae) infection in Korea. The Korean Journal of Parasitology 33, 219-223. 
Eiras, J.C. (1994) Elementos de ictioparasitologia. 339 pp. Porto, Fundação Eng. Antônio de Almeida.

Eiras, J.C., Takemoto, R.M. \& Pavanelli, G.C. (2006) Métodos de estudo e técnicas laboratoriais em parasitologia de peixes. 2nd edn. 199 pp. Maringá, Eduem.

Fernandes, B.M.M. \& Kohn, A. (2001) On some trematode parasites of fishes from Paraná River. Brazilian Journal of Biology 61, 461-466.

Gibson, D.I., Margolis, L. \& Kabata, Z. (1996) Guide to the parasites of fishes of Canada. Part 4. Trematoda. 382 pp. Ottawa, National Research Council of Canada.

Kitagawa, N., Oda, M., Totoki, T., Washizaki, S., Oda, M. \& Kifune, T. (2003) Lidocaine spray used to capture a live Clinostomum parasite causing human laryngitis. American Journal of Otolaryngology 24, 341-343.

Klein, S., Feiden, A., Boscolo, W.R., Reidel, A., Signor, A. \& Signor, A.A. (2004) Utilização de produtos químicos no controle de Ichthyophthirius multifiliis, Fouquet (1876) em alevinos de surubim do Iguaçu Steindachneridion sp., Garavello (1991). Semina: Ciências Agrárias 25, 51-58.

Knoff, M., Clemente, S.C.S., Fonseca, M.C.G., Andrada, C.G., Padovani, R.E.S. \& Gomes, D.C. (2007) Anisakidae parasitos de congro-rosa, Genypterus brasiliensis Regan, 1903 comercializados no Estado do Rio de Janeiro, Brasil de interesse na saúde pública. Parasitología Latinoamericana 62, 127-133.

Kohn, A. \& Fernandes, B.M.M. (1981) The adult form of Himasthla piscicola Stunkard, 1960 and other trematodes from Brazilian freshwater fishes. Journal of Helminthology 55, 85-87.

Kohn, A., Fernandes, B.M.M., Pipolo, H.V. \& Godoy, M.P. (1988) Helmintos parasitos de peixes das usinas hidreléticas da Eletrosul (Brasil) II: Reservatórios de Salto Osório e de Salto Santiago, Bacia do Rio Iguaçu. Memórias do Instituto Oswaldo Cruz 83, 299-303.

Kohn, A., Fernandes, B.M.M., Pipolo, H.V. \& Godoy, M.P. (1989) List of helminth parasites of fishes from the Passo Fundo Reservoir, Uruguay River Basin, Brazil. Memórias do Instituto Oswaldo Cruz 84, 427-428.

Kohn, A., Fernandes, B.M.M. \& Baptista-Farias, M.F.D. (1995) Metacercariae of Diplostomum (Austrodiplostomum) compactum (Trematoda, Diplostomidae) in the eyes of Plagioscion squamosissimus (Teleostei, Sciaenidae) from the reservoir of the Hydroelectric Power Station of Itaipu, Brazil. Memórias do Instituto Oswaldo Cruz 90, 341-344.

Krebs, C.J. (1989) Ecological methodology. 1st edn. 654 pp. New York, Harper Collins.

Kullander, S.O. (1998) A phylogeny and classification of the South American Cichlidae (Teleostei: Perciformes). pp. 461-498 in Malabarba, L.R., Reis, R.E., Vari, R.P., Lucena, Z.M.S. \& Lucena, C.A.S. (Eds) Phylogeny and classification of Neotropical fishes. Porto Alegre, Edipucrs.

Kullander, S.O. (2003) Family Cichlidae (Cichlids). pp. 605-654 in Reis, R.E., Kullander, S.O. \& Ferraris, C.J. Jr (Eds) Checklist of the freshwater fishes of South and Central America. Porto Alegre, Edipucrs.

Langeani, F., Corrêa e Castro, R.M., Oyakawa, O.T., Shibatta, O.A., Pavanelli, C.S. \& Casatti, L. (2007) Diversidade da ictiofauna do Alto Rio Paraná: composição atual e perspectivas futuras. Biota Neotropica 7, 181-197.
Le Cren, E.D. (1951) The length-weight relationship and seasonal cycle in gonad weight and condition in the perch (Perca fluviatilis). Journal of Animal Ecology 20, 201-219.

Machado, M.H., Pavanelli, G.C. \& Takemoto, R.M. (1996) Structure and diversity of endoparasitic infracommunities and the trophic level of Pseudoplatystoma corruscans and Schizodon borelli (Osteichthyes) of the High Paraná River. Memórias do Instituto Oswaldo Cruz 91, 441-448.

Machado, P.M., Takemoto, R.M. \& Pavanelli, G.C. (2005) Diplostomum (Austrodiplostomum) compactum (Lutz, 1928) (Platyhelminthes, Digenea) metacercariae in fish from the floodplain of the Upper Paraná River, Brazil. Parasitology Research 97, 436-444.

Madi, R.R. (2005) Utilização dos helmintos parasitos de Geophagus brasiliensis (Quoy \& Gaimard, 1824) (Cichlidae; Perciformes) como indicadores ambientais. Masters Dissertation, Universidade de Campinas Unicamp, Campinas (SP). Available at website: http:/ / www.bibliotecadigital.unicamp.br/document/ ?code=vtls000359415 (accessed 17 July 2011).

Milward-de-Andrade, R. (1959) Ecologia. Revista Brasileira de Malariologia e Doenças Tropicais 11, 171-218.

Moraes, J., Silva, M.P.N., Ohlweiler, F.P. \& Kawano, T. (2009) Schistosoma mansoni and other larval trematodes in Biomphalaria tenagophila (Planorbidae) from Guarulhos, São Paulo State, Brazil. Revista do Instituto de Medicina Tropical de São Paulo 51, 77-82.

Moravec, F., Kohn, A. \& Fernandes, B.M.M. (1990) First record of Raphidascaris (Sprentascaris) hypostomi (Petter et Cassone, 1984) comb. n. and R. (S.) mahnerti (Petter et Cassone, 1984) comb. n. (Nematoda: Anisakidae) from Brazil with remarks on the taxonomic status of the genus Sprentascaris Petter et Cassone, 1984. Folia Parasitologica 37, 131-140.

Moravec, F., Kohn, A. \& Fernandes, B.M.M. (1993) Nematode parasites of fishes of the Paraná River, Brazil. Part 2. Seratoidea, Ascaridoidea, Habronematoidea and Acuarioidea. Folia Parasitologica 40, 115-134.

Moretto, E.M., Marciano, F.T., Velludo, M.R., FenerichVerani, N., Espíndola, E.L.G. \& Rocha, O. (2008) The recent occurrence, establishment and potential impact of Geophagus proximus (Cichlidae: Perciformes) in the Tietê River reservoirs: an Amazonian fish species introduced in the Paraná Basin (Brazil). Biodiversity Conservation 17, 3013-3025.

O’Neill, J.G., White, M.G., Sims, T.A. \& Barber, D.L. (1988) An inflammatory response of the antarctic silverfish, Pleuragramma antarcticum Boulenger 1902 (Teleostei: Notothenioidei) to infestation by the plerocercoid of a pseudophyllidean cestode (Diphyllobothrium sp.). British Antarctic Survey 79, 51-63.

Paes, J.V.K., Carvalho, E.D. \& Silva, R.J. (2010a) Infection levels of Austrodiplostomum compactum (Digenea, Diplostomidae) metacercariae in Plagioscion squamosissimus (Teleostei, Sciaenidae) from the Nova Avanhandava reservoir, São Paulo State, Brazil. Journal of Helminthology 84, 284-291.

Paes, J.V.K., Carvalho, E.D. \& Silva, R.J. (2010b) Infection by Diplostomum (Austrodiplostomum) compactum metacercariae in fishes from the Nova Avanhandava 
Reservoir, Tietê River, São Paulo, Brazil. Acta Scientiarum Biological Sciences 32, 273-278.

Paraguassú, A.R., Alves, D.R. \& Luque, J.L. (2005) Metazoários parasitos do acará Geophagus brasiliensis (Quoy: Gaimard, 1824) (Osteichthyes: Cichlidae) do reservatório de Lajes, Estado do Rio de Janeiro, Brasil. Revista Brasileira de Parasitologia Veterinária 14, 35-39.

Pinto, R.M., Fábio, S.P., Noronha, D. \& Tayt-Son Rolas, F.J. (1976) Novas considerações morfológicas e sistemáticas sobre os Procamallanus brasileiros (Nematoda, Camallanoidea). Memórias do Instituto Oswaldo Cruz 74, 77-93.

Poulin, R. (1995) Phylogeny, ecology, and the richness of parasite communities in vertebrates. Ecological Monographs 65, 283-302.

Poulin, R. (2007) Evolutionary ecology of parasites. 2nd edn. 332 pp. Princeton, Princeton University Press.

Rego, A.A. \& Pavanelli, G.C. (1990) Novas espécies de cestóides proteocephalideos parasitas de peixes não siluriformes. Revista Brasileira de Biologia 50, 91-101.

Rego, A.A., Chubb, J.C. \& Pavanelli, G.C. (1999) Cestodes in South American freshwater teleost fishes: keys to genera and brief description of species. Revista Brasileira de Zoologia 16, 299-367.

Rozsa, L., Reiczigel, J. \& Majoros, G. (2000) Quantifying parasites in samples of hosts. Journal of Parasitology 86, $228-232$.

Sakanari, J.A. \& McKerrow, J.H. (1990) Identification of the secreted neutral proteases from Anisakis simplex. Journal of Parasitology 76, 625-630.

Santos, R.S., Pimenta, F.D.A., Martins, M.L., Takahashi, H.K. \& Marengoni, N.G. (2002) Metacercárias de Diplostomum (Austrodiplostomum) compactum Lutz, 1928 (Digenea, Diplostomidae) em peixes do rio Paraná, Brasil: prevalência, sazonalidade e intensidade de infecção. Acta Scientiarum Biological Sciences 24, 475-480.

Silva, A.S., Monteiro, S.G., Doyle, R.L., Pedron, F.A., Filipetto, J.E.S. \& Neto, J.R. (2008) Ocorrência de Clinostomum complanatum em diferentes espécies de peixes de uma piscicultura do município de Santa Maria - RS. Veterinária e Zootecnia 15, 27-32.

Silva, L.O., Luque, J.L., Alves, D.R. \& Paraguassú, A.R. (2000) Ecologia da comunidade de metazoários parasitos do peixe-espada Trichiurus lepturus Linnaeus (Osteichthyes, Trichiuridae) do litoral do Estado do Rio de Janeiro, Brasil. Revista Brasileira de Zoociências 2, 115-133.
Sohn, W.M. \& Seol, S.Y. (1994) A human case of gastric anisakiasis by Pseudoterranova decipiens larva. The Korean Journal of Parasitology 32, 53-56.

Takemoto, R.M., Pavanelli, G.C., Lizama, M.A.P., Lacerda, A.C.F., Yamada, F.H., Moreira, L.H.A., Ceschini, T.L. \& Bellay, S. (2009) Diversity of parasites of fish from the Upper Paraná River floodplain, Brazil. Brazilian Journal of Biology 69, 691-705.

Thatcher, V.E. (2006) Amazon fish parasites. 2nd edn. 508 pp. Bulgaria, Pensoft.

Tiewchaloern, S., Udomkijdecha, S., Suvouttho, S., Chunchamsri, K. \& Waikagul, J. (1999) Clinostomum trematode from human eye. The Southeast Asian Journal of Tropical Medicine and Public Health 30, 382-384.

Travassos, J.F.L., Freitas, T. \& Kohn, A. (1969) Trematódeos do Brasil. Memórias do Instituto Oswaldo Cruz 67, $1-886$.

Yamada, F.H., Moreira, L.H.A., Ceschini, T.L., Takemoto, R.M. \& Pavanelli, G.C. (2008) Novas ocorrências de metacercária de Austrodiplostomum compactum (Lutz, 1928) (Platyhelminthes: Digenea) parasito de olhos de peixes da bacia do rio Paraná. Revista Brasileira de Parasitologia Veterinária 17, 163-166.

Zica, E.O.P., Santos, K.R., Ramos, I.P., Zanatta, A.S., Carvalho, E.D. \& Silva, R.J. (2009) First case of an infection of the metacercariae of Austrodiplostomum compactum (Lutz, 1928) (Digenea, Diplostomidae) in Hypostomus regani (Ihering, 1905) (Siluriformes: Loricariidae). Pan-American Journal of Aquatic Sciences 4, 35-38.

Zica, E.O.P., Wunderlich, A.C., Ramos, I.P. \& Silva, J.R. (2010) Austrodiplostomum compactum (Lutz, 1928) (Digenea, Diplostomidae) infecting Geophagus proximus Castelnau, 1855 (Cichlidae, Perciformes) in the Tietê River, Nova Avanhandava Reservoir, municipality of Buritama, São Paulo State, Brazil. Neotropical Helminthology 4, 9-15.

Zica, E.O.P., Brandão, H., Zawadzki, C.H., Nobile, A.B., Carvalho, E.D. \& Silva, R.J. (2011) The occurrence of Austrodiplostomum compactum (Lutz, 1928) (Digenea: Diplostomidae) metacercariae in the eyes of loricariid fish (Siluriformes: Osteichthyes: Loricariidae) from Brazil. Journal of Helminthology 85, 73-79.

Zuben, C.J.V. (1997) Implicações da agregação espacial de parasitas para a dinâmica populacional na interação hospedeiro-parasita. Revista de Saúde Pública 31, 523-530. 